\title{
Piotr Prewysz-Kwinto
}

Wyższa Szkoła Bankowa w Toruniu

e-mail: piotr.kwinto@wsb.torun.pl

\section{PREZENTACJA INFORMACJI O KOSZTACH I INNYCH CALKOWITYCH DOCHODACH WEDLUG MIECDZYNARODOWYCH STANDARDÓW RACHUNKOWOŚCI I NA PRZYKLADZIE GRUP KAPITALOWYCH NOTOWANYCH NA GPW W WARSZAWIE}

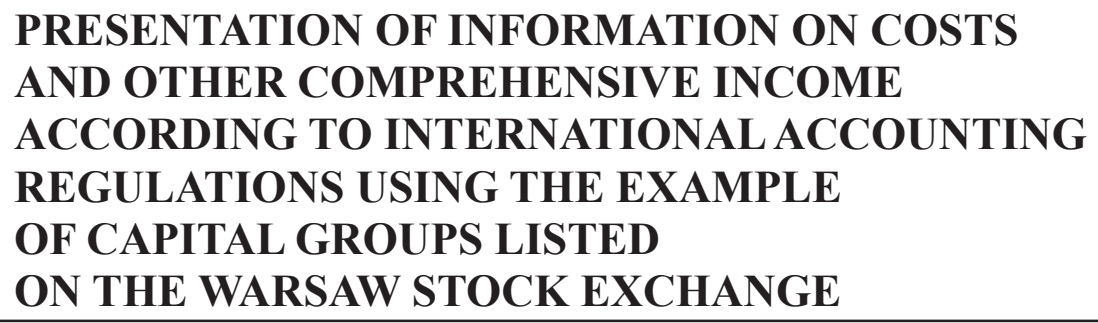

DOI: $10.15611 / \mathrm{pn} .2018 .524 .11$

JEL Classification: M41, M48.

Streszczenie: Wynik finansowy należy do najważniejszych kategorii ekonomicznych wykorzystywanych przez użytkowników do oceny sytuacji finansowej jednostki oraz jej kadry zarządzającej. Zasady jego ustalania i prezentacji w sprawozdaniu finansowym określają normy rachunkowości, które w ostatnich latach ulegały w tym zakresie dość dużym zmianom. W opracowaniu przedstawiono najważniejsze aspekty dotyczące prezentacji informacji o kosztach i innych całkowitych dochodach w świetle rozwiązań zawartych w międzynarodowych standardach rachunkowości oraz zwrócono uwagę na problemy z tym związane. Zasadniczą jego część stanowi jednak prezentacja wyników przeprowadzonego badania sześćdziesięciu grup kapitałowych notowanych na Giełdzie Papierów Wartościowych w zakresie sposobu prezentacji informacji w sprawozdaniu z całkowitych dochodów. Badaniem objęto skonsolidowane sprawozdania finansowe za lata 2015-2017, a otrzymane wyniki odniesiono do rezultatów wcześniejszych badań prowadzonych w tym zakresie.

Słowa kluczowe: sprawozdanie finansowe, koszty, inne całkowite dochody, dochód całkowity, MSR/MSSF, standardy rachunkowości.

Summary: Profit (or loss) is one of the most important economic categories used to assess the financial position of an entity and its management. The rules for its presentation in the financial statements are set out in accounting standards which have been subject to quite large 
changes in recent years. The study presents the most important aspects regarding the presentation of information on costs and other comprehensive income according to international accounting regulations. The results of the research of financial statements of the sixty largest capital groups listed on the Warsaw Stock Exchange regarding the presentation of this information in the statement of comprehensive income have also been presented.

Keywords: financial statement, costs, other comprehensive income, comprehensive income, IAS/IFRS, accounting regulations.

\section{Wstęp}

Zasady prezentacji informacji finansowych zostały szczegółowo uregulowane w MSR 1 „Prezentacja sprawozdań finansowych”, który został po raz pierwszy uchwalony w sierpniu 1997 roku, zastępując trzy wcześniej stosowane w tym zakresie standardy. Do dnia dzisiejszego MSR 1 był kilka razy zmieniany. Z punktu widzenia prezentacji informacji o kosztach działalności i wyniku finansowym największa zmiana miała miejsce w roku 2007 z obowiązkiem zastosowania wprowadzonych rozwiązań do sprawozdań finansowych sporządzanych po 1 stycznia 2009 roku. Zmiana ta polegała na wprowadzeniu do sprawozdania finansowego koncepcji wyniku całościowego, zastępując tym samym tradycyjny rachunek zysków i strat nowym sprawozdaniem z całkowitych dochodów.

Celem opracowania jest syntetyczne przedstawienie zasad prezentacji informacji o kosztach i innych całkowitych dochodach w świetle rozwiązań zawartych w międzynarodowych standardach rachunkowości oraz analiza sposobu prezentacji tych informacji przez największe grupy kapitałowe notowane na GPW w Warszawie, z uwzględnieniem wyników wcześniejszych badań prowadzonych w tym zakresie. Przed rozpoczęciem analizy sformułowano następującą hipotezę badawczą: sposób prezentacji informacji dotyczących kosztów i innych całkowitych dochodów w sprawozdaniu finansowym jest zróżnicowany i wynika ze swobody, jaką daje w tym zakresie MSR 1.

Realizacji postawionego celu dokonano na podstawie analizy dostępnej literatury przedmiotu, w tym rozwiązań ujętych w międzynarodowych standardach rachunkowości (metoda analizy źródeł) oraz analizy informacji prezentowanych w sprawozdaniach z całkowitych dochodów największych grup kapitałowych notowanych na GPW w Warszawie za okres 2015-2017. W analizie ilościowej wykorzystano metody statystki opisowej.

Opracowanie składa się z dwóch części. W pierwszej przedstawiono najważniejsze aspekty i problemy dotyczące sporządzania sprawozdania z całkowitych dochodów według MSR/MSSF. W drugiej zaprezentowano wyniki przeprowadzonego badania, dotyczącego sposobu prezentacji kosztów i innych całkowitych dochodów w sprawozdaniach finansowych sześćdziesięciu grup kapitałowych. 


\section{Sprawozdanie z calkowitych dochodów w świetle międzynarodowych standardów rachunkowości}

Koncepcja całościowego dochodu (comprehensive income - CI) wiąże się z koniecznością uwzględniania $\mathrm{w}$ wyniku finansowym jednostki również zdarzeń, które wcześniej ujmowane były w kapitale własnym. Wynika to bezpośrednio z definicji całościowego dochodu, zawartej w MSR 1, zgodnie z którą dochód całkowity to zmiany w kapitale własnym, które nastąpiły w ciągu okresu na skutek transakcji gospodarczych oraz innych zdarzeń, z wyjątkiem transakcji dokonywanych z właścicielami występującymi w charakterze udziałowców [MSR1, par. 7]. Tym samym sprawozdanie z całkowitych dochodów obejmuje dotychczasowy wynik finansowy jednostki ustalony w tradycyjnym rachunku zysków i strat, który następnie koryguje się o inne całkowite dochody (other comprehensive income - OCI), ujmowane dotychczas w kapitale własnym. Koncepcja całościowego dochodu jest więc zdaniem E. Walińskiej i A. Jurewicz próbą „oczyszczenia” kapitału własnego z przychodów i kosztów, czyli kategorii niezależnych od właścicieli tego kapitału [Walińska, Jurewicz 2011, s. 27]. Elementy, które zalicza się do innych całkowitych dochodów, a które były wcześniej ujmowane w kapitale własnym, zostały szczegółowo przedstawione w paragrafie 7 MSR 1 . Ze względu na obszerność tego opracowania nie będą tutaj wymieniane.

Wprowadzenie koncepcji całkowitego dochodu do sprawozdawczości finansowej jest związane ze wzrostem znaczenia koncepcji zarządzania wartością i rozumienia zysku jako przyrostu dobrobytu (bogactwa) właścicieli [Szychta 2011, s. 82; Gierusz 2014, s. 190], a także coraz większego zapotrzebowania użytkowników na informacje o charakterze prospektywnym [Gierusz 2014, s. 190; Emerling 2014, s. 44].

Omawiając sprawozdanie z całkowitych dochodów, należy przede wszystkim zaznaczyć, że w przeciwieństwie do rozwiązań krajowych zawartych w ustawie o rachunkowości, która w załącznikach narzuca konkretne wzorce rachunku zysków i strat dla poszczególnych typów podmiotów, MSR 1 pozostawia bardzo dużą swobodę $\mathrm{w}$ zakresie formy prezentacji informacji dotyczących całościowego wyniku i wewnętrznej struktury tego dokumentu. Swoboda ta sprowadza się między innymi do [Bek-Gaik 2013a, s. 27]:

- formy prezentacji sprawozdania z całościowego wyniku finansowego,

- sposobu prezentacji kosztów,

- sposobu ujmowania podatku dochodowego,

- obowiązku prezentacji innych całkowitych dochodów.

Sporządzając sprawozdanie z całkowitych dochodów, jednostki mają prawo wyboru jednej z dwóch form prezentacji, tzn. jednego dokumentu obejmującego bieżący wynik finansowy skorygowany o inne całkowite dochody lub dwóch odrębnych zestawień, tj. rachunku zysków i strat oraz sprawozdania z całkowitych dochodów, które rozpoczyna się wówczas od zysku netto. Niezależnie od wyboru formy prezentacji MSR 1, w przeciwieństwie do ustawy o rachunkowości, nie narzuca jednej, 
stałej jego struktury, ale podaje tylko minimalny zakres informacji, które powinny być zaprezentowane. W części dotyczącej rachunku zysków i strat są to następujące pozycje [MSR 1, par. 82]:

- przychody,

- koszty finansowe,

- udziały w zyskach lub stratach jednostek stowarzyszonych i wspólnych przedsięwzięć rozliczanych zgodnie z metodą praw własności,

- obciążenia z tytułu podatków,

- łączna kwota obejmująca sumy działalności zaniechanej.

Ograniczenie się tylko do wskazania przez standard minimalnego zakresu informacji, jakie powinny zostać zaprezentowane, i brak przykładowej (zalecanej) jego struktury spowodował, że od kilku lat międzynarodowe firmy audytorskie i doradcze opracowują i publikują wzorcowe skonsolidowane sprawozdania finansowe według MSSF [Deloitte 2015; PWC 2015]. Zawierają one wzorcową (przykładową) strukturę poszczególnych elementów sprawozdania finansowego, w tym sprawozdania z całkowitych dochodów, i to zarówno w formie jednego, jak i dwóch zestawień. Wzorce te, jak pokazuje przeprowadzone badanie, są z powodzeniem wykorzystywane przez podmioty przy sporządzaniu własnych sprawozdań finansowych.

Swoboda w sporządzaniu sprawozdania z całkowitych dochodów polega również na tym, że zgodnie z paragrafem 99 MSR 1 jednostka ma prawo wybrać sposób prezentacji informacji o kosztach działalności podstawowej, tj. według rodzaju (wariant porównawczy) lub według miejsc powstawania i nośników kosztów (wariant kalkulacyjny). Przy wyborze odpowiedniego wariantu standard nakazuje kierować się wiarygodnością i przydatnością informacji. Ponadto wpływ w wybór powinny mieć również czynniki historyczne, uwarunkowania danego sektora czy rodzaj działalności jednostki [MSR 1, par 105].

Jeżeli chodzi o informacje dotyczące innych całkowitych dochodów, to MSR 1 daje swobodę wyboru sposobu ich prezentacji, tj. w kwotach netto, czyli uwzględniając od razu skutki podatkowe, jakie wywołują, lub w kwotach brutto, czyli z wykazaniem w odrębnej pozycji łącznej kwoty podatku dochodowego odnoszącego się do OCI [MSR 1, par. 91]. Standard nakłada jednak obowiązek prezentacji informacji dotyczących OCI z podziałem na dwie odrębne kategorie, tj. te, które nie zostaną przeklasyfikowane na zyski lub straty, oraz te, które zostaną na nie przeklasyfikowane po spełnieniu określonych warunków. Obowiązek takiej prezentacji został wprowadzony dopiero kolejną nowelizacją MSR 1, która miała miejsce w czerwcu 2011 roku z obowiązkiem zastosowania od 1 lipca 2012. Wprowadzona zmiana miała w założeniach zwiększyć przejrzystość informacji o wyniku całościowym oraz ułatwić ich porównywanie [Strojek-Filus 2015, s. 135], a także zbliżyć rozwiązania zawarte w MSR do rozwiązań amerykańskich zawartych w US GAAP [Hołda 2013, s. 50].

Warto również wskazać, że swoboda w kształtowaniu tego elementu sprawozdania finansowego nie sprowadza się tylko do wyboru sposobu i zasad prezentacji 
informacji dotyczących bieżącego wyniku operacyjnego czy innych całkowitych dochodów, ale również stosowanego nazewnictwa. Dotyczy to zarówno samej nazwy tego sprawozdania, jak i poszczególnych jego elementów. Taka swoboda w określaniu poszczególnych pozycji, jak zauważają liczni autorzy, może jednak prowadzić do chaosu pojęciowego i utrudniać porównywalność informacji zawartych w sprawozdaniu finansowym między poszczególnymi podmiotami [Buk 2013, s. 13; Sajnóg 2014, s. 482].

Problematyka całkowitego dochodu stanowi do dnia dzisiejszego przedmiot licznych badań empirycznych prowadzonych na świecie, jak również w naszym kraju. Wyniki badań zagranicznych zostały szerzej przedstawione w publikacjach K. Grabińskiego [2012, s. 52-54] oraz B. Bek-Gaik [2013a, s. 28-32; 2013b, s. 218-228]. Należy wskazać, jak zauważa M. Strojek-Filus, że badania te koncentrują się na trzech zasadniczych obszarach. Są to [Strojek-Filus 2015, s. 129]:

- badania dotyczące wyboru sposobu prezentacji informacji o całkowitym dochodzie,

- badania dotyczące wpływu przyjętych rozwiązań w zakresie prezentacji na ocenę sytuacji finansowej jednostki,

- badania dotyczące wpływu informacji na temat OCI oraz całkowitego dochodu na cenę rynkową akcji i decyzje inwestorów.

Prowadzone badania skupiają się więc z jednej strony na ocenie zasad prezentacji informacji w sprawozdaniu z całkowitych dochodów, z drugiej zaś na ich przydatności w procesie podejmowania decyzji ekonomicznych i w ocenie dokonań jednostki.

W naszym kraju badania empiryczne w zakresie całościowego dochodu prowadziło wielu badaczy, w tym między innymi: A. Szychta, E. Walińska, B. Bek-Gaik, E. Winnicka, A. Sajnóg, J. Gad. Formułowane przez nich wnioski są podobne i wskazują przede wszystkim na dużą trudność w porównywaniu informacji dotyczących innych całkowitych dochodów między spółkami ze względu na dużą swobodę ich prezentacji w sprawozdaniu finansowym. Dotyczy to zarówno wspomnianego już nazewnictwa, jak i formy oraz struktury samego dokumentu (np. [Szychta 2012, s. 80; Bek-Gaik 2013a, s. 33; Sajnóg 2014, s. 482]). Brak przejrzystości i porównywalności prezentowanych informacji może sprawiać problemy w podejmowaniu przez interesariuszy trafnych decyzji ekonomicznych [Winnicka 2013, s. 186]. Prezentowane wyniki zachęciły do przeprowadzenia kolejnego badania w tym zakresie. Jego celem była weryfikacja, czy po 10 latach od momentu wprowadzenia koncepcji całkowitego dochodu do międzynarodowych standardów rachunkowości wnioski $\mathrm{z}$ wcześniej prowadzonych badań pozostają nadal aktualne. Analizie poddano sprawozdania z całkowitych dochodów sześćdziesięciu grup kapitałowych notowanych na GPW w Warszawie za lata 2015-2017. Uzyskane wyniki zostały zaprezentowane w dalszej części opracowania. 


\section{Prezentacja informacji o kosztach i innych całkowitych dochodach w sprawozdaniach finansowych największych grup kapitałowych notowanych na GPW w Warszawie}

\subsection{Metodyka badania i charakterystyka grupy badanej}

Badaniem objęto największe grupy kapitałowe notowane na Giełdzie Papierów Wartościowych w Warszawie, tj. wchodzące w dniu 15 maja 2018 roku w skład dwóch głównych jej indeksów: WIG20 oraz mWIG40. Reprezentowały one różne branże, które szczegółowo przedstawia tabela 1.

Tabela 1. Grupy kapitałowe objęte badaniem według prowadzonej działalności

\begin{tabular}{|r|l|c|c|}
\hline Lp. & \multicolumn{1}{|c|}{ Branża } & $\begin{array}{c}\text { Liczba grup } \\
\text { kapitałowych }\end{array}$ & Udział \\
\hline 1 & Budownictwo i deweloperzy & 4 & $6,7 \%$ \\
\hline 2 & Chemiczna i paliwowa & 5 & $8,3 \%$ \\
\hline 3 & Drzewna i papiernicza & 2 & $3,3 \%$ \\
\hline 4 & Elektromaszynowa & 2 & $3,3 \%$ \\
\hline 5 & Energetyczna & 4 & $6,7 \%$ \\
\hline 6 & Finansowa & 12 & $20,0 \%$ \\
\hline 7 & Handel detaliczny i hurtowy & 6 & $10,0 \%$ \\
\hline 8 & Informatyczna & 6 & $10,0 \%$ \\
\hline 9 & Metalowa & 3 & $5,0 \%$ \\
\hline 10 & Motoryzacyjna & 2 & $5,0 \%$ \\
\hline 11 & Spożywcza & 3 & $3,3 \%$ \\
\hline 12 & Telekomunikacyjna & 3 & $5,0 \%$ \\
\hline 13 & Wydobywcza & 5 & $5,0 \%$ \\
\hline 14 & Inna & 60 & $8,3 \%$ \\
\hline 15 & Razem & & $100,0 \%$ \\
\hline
\end{tabular}

Źródło: opracowanie własne.

W badanej grupie największy udział miały podmioty z branży finansowej (banki i firmy ubezpieczeniowe) - 20\% oraz informatycznej - $10 \%$. W pozycji ,inne” znalazły się grupy kapitałowe reprezentujące takie branże, jak: gastronomiczna, hotelarska, medyczna, transportowa oraz inne usługi. Wszystkie podmioty jako grupy kapitałowe notowane na GPW, zgodnie z ustawą o rachunkowości, sporządzały sprawozdania finansowe według standardów międzynarodowych MSR/MSSF. W analizie dla porównania wyników uwzględniono skonsolidowane sprawozdania kolejno za rok obrotowy 2015, 2016, 2017 lub kończący się w tych latach, jeśli dzień bilansowy był ustalony na inny dzień niż 31 grudnia. 


\subsection{Wyniki przeprowadzonego badania}

Badanie rozpoczęto od określenia, jaką formę prezentacji sprawozdania z wyniku wybierały badane grupy kapitałowe. Zgodnie z MSR 1 podmioty nim objęte mają możliwość wyboru jednego zestawienia (sprawozdanie z całkowitych dochodów) lub dwóch odrębnych, tj. rachunku zysków i strat oraz sprawozdania z całkowitych dochodów. Uzyskane wyniki prezentuje rys. 1.

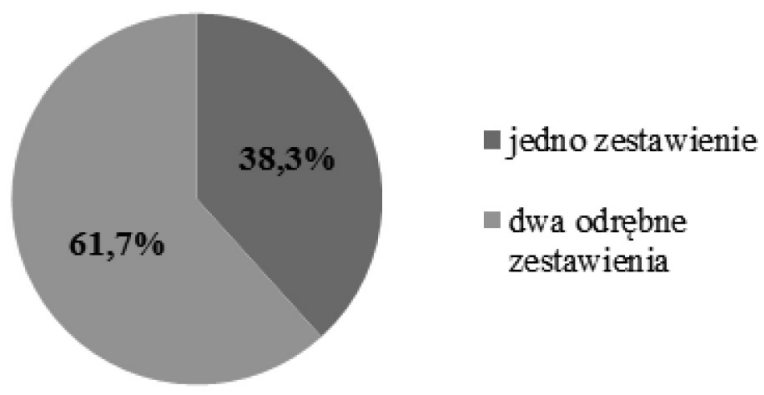

Rys. 1. Forma sporządzania sprawozdania z całkowitych dochodów

Źródło: opracowanie własne na podstawie przeprowadzonego badania.

Jak wynika $\mathrm{z}$ rys. 1 , badane grupy częściej wybierały prezentację informacji o wyniku finansowym w ramach dwóch odrębnych zestawień - $61,7 \%$, niż jednego dokumentu - 38,3\%. Uzyskane wyniki potwierdzają wnioski płynące z wcześniejszych badań prowadzonych przez B. Bek-Gaik, A. Szychtę, E. Winnicką oraz J. Gada, a także z badań międzynarodowych ${ }^{1}$. Wybór dwóch odrębnych sprawozdań może być, jak sugeruje A. Szychta, spowodowany przyzwyczajeniem księgowych do tradycji sporządzania rachunku zysków i strat [Szychta 2012, s. 72]. Może on również wynikać z chęci lepszego uwypuklenia różnic między bieżącym wynikiem operacyjnym a całkowitym dochodem, gdyż to bieżący wynik operacyjny stanowi wciąż podstawę oceny dokonań jednostki oraz jej zarządu.

Dokonując bardziej szczegółowej analizy ze względu na wielkość badanej grupy (mierzoną przynależnością odpowiednio do indeksu WIG20 lub mWIG40), nie zauważono większych różnic. Prezentację informacji o wyniku finansowym w ramach dwóch odrębnych zestawień wybrało $65 \%$ podmiotów wchodzących w skład indeksu WIG20 oraz 60\% tych z indeksu mWIG40. Drugi sposób, czyli prezentację

\footnotetext{
${ }^{1} \mathrm{~W}$ badaniu B. Bek-Gaik prezentację wyniku całościowego w ramach dwóch odrębnych zestawień stosowało 60\% z 31 podmiotów [Bek-Gaik 2013b, s. 296], w badaniu E. Winnickiej 73,6\% z 19 podmiotów [Winnicka 2013, s. 174-175], w badaniu A. Szychty 75\% spośród 24 podmiotów [Szychta 2012, s. 72], a w badaniu J. Gada odpowiednio 60\% w 2012 i 63,3\% w roku 2013 i 2014 spośród 30 badanych podmiotów [Gad 2016, s. 122]. Natomiast w badaniu O. Ferraro na 160 spółek notowanych na giełdzie w Mediolanie taki sposób prezentacji wybrało $84 \%$.
} 
w ramach jednego dokumentu, wybrało 35\% grup z indeksu WIG20 i 40\% tych z indeksu mWIG40. Należy również wskazać, że szczegółowa analiza ze względu na rodzaj prowadzonej działalności pozwoliła wnioskować, że w przypadku niektórych branż częściej wybierano konkretny typ prezentacji. Prezentacja w ramach dwóch odrębnych zestawień znacznie częściej występowała w branży finansowej $(91,7 \%)$, przy czym stosowały ją wszystkie badane banki, a także w branży budowlanej i deweloperskiej (75\%). Prezentację w ramach jednego dokumentu częściej wybierały podmioty branży energetycznej- $75 \%$. Warto dodać, że w okresie trzech badanych lat żadna $z$ grup kapitałowych nie zmieniła formy stosowanej prezentacji informacji dotyczących wyniku finansowego (z jednego dokumentu na dwa lub odwrotnie). Oznaczać to może, że badane grupy przyzwyczaiły się już do nowej formy sprawozdania i wypracowały rozwiązania najlepiej im odpowiadające.

Na podkreślenie zasługuje również fakt, że samo sprawozdanie dotyczące wyniku finansowego nosiło różne nazwy. Taką możliwość daje sam MSR 1. W przypadku grup kapitałowych, które przygotowywały dwa oddzielne dokumenty, najczęściej $(72,9 \%)$ określano je nazwami zawartymi w standardzie, tj.: ,skonsolidowany rachunek zysków i strat oraz skonsolidowane sprawozdanie z całkowitych dochodów", ale znalazły się również takie określenia jak: „skonsolidowane sprawozdanie z wyniku” lub „skonsolidowane sprawozdanie z zysków lub strat” w przypadku pierwszego oraz „sprawozdanie z innych (pozostałych) całkowitych dochodów” w przypadku drugiego dokumentu. Podmioty, które prezentowały wszystkie informacje o wyniku w ramach jednego zestawienia najczęściej $(52,2 \%)$ określały je mianem ,skonsolidowane sprawozdanie $\mathrm{z}$ całkowitych dochodów". Pojawiały się również następujące nazwy: „skonsolidowane sprawozdanie z wyniku finansowego i (innych lub pozostałych) dochodów całkowitych” czy „skonsolidowane sprawozdanie z zysków i (lub) strat i innych całkowitych dochodów".

Kolejnym etapem przeprowadzonego badania była analiza sposobu prezentacji w rachunku wyników informacji o kosztach działalności. Rozpoczęto ją od określenia wariantu sporządzania tego dokumentu, a zatem czy koszty działalności podstawowej prezentowane były według ich rodzaju (wariant porównawczy) czy według miejsca powstawania i nośników kosztów (wariant kalkulacyjny). Z analizy wyłączono sprawozdania finansowe banków i podmiotów prowadzących działalność ubezpieczeniową (10 grup kapitałowych), gdyż sporządzają one rachunek wyników według odrębnych - specyficznych dla tych podmiotów - zasad. Analizie poddano zatem sprawozdania 50 grup kapitałowych. Otrzymane wyniki pokazały, że większość zdecydowała się na prezentację kosztów działalności podstawowej zgodnie z układem kalkulacyjnym (76\%). Drugi wariant - układ porównawczy - stosowało $22 \%$ badanych. Warto dodać, że w przypadku jednej grupy kapitałowej analiza samego rachunku wyników nie pozwoliła na jednoznaczną ocenę, który wariant został zastosowany, gdyż przychodom ze sprzedaży przeciwstawiono tylko jedną zbiorczą pozycję nazwaną ,koszty operacyjne”, która po korekcie o pozostałe przychody operacyjne dała od razu wynik operacyjny. 
Analizując uzyskane wyniki ze względu na wielkość badanej grupy, te większe z indeksu WIG20 częściej wybierały prezentację kosztów działalności podstawowej według miejsc powstawania i nośników kosztów - 84,6\%, wariant porównawczy stosowało natomiast $15,4 \%$ badanych. Dla grup mniejszych z indeksu mWIG40 odsetek ten wyniósł odpowiednio $75 \%$ dla wariantu kalkulacyjnego i $25 \%$ dla wariantu porównawczego. Wariant kalkulacyjny wybrały wszystkie grupy kapitałowe z branży: budowlanej, drzewnej, elektromaszynowej, handlu detalicznego i hurtowego, motoryzacyjnej, spożywczej oraz wydobywczej. Wariant porównawczy dominował natomiast wśród grup kapitałowych z branży telekomunikacyjnej oraz medialnej.

Należy dodać, że grupy kapitałowe, które wybrały prezentację informacji o kosztach w układzie kalkulacyjnym, dokonywały tego w sposób klasyczny, tj. przedstawiając odrębnie koszt wytworzenia sprzedanych produktów oraz koszty okresu, czyli koszty sprzedaży (określane też w niektórych przypadkach mianem „koszty sprzedaży i marketingu” lub „koszty sprzedaży i dystrybucji”) oraz koszty ogólnego zarządu (określane też mianem „koszty administracyjne” lub koszty „ogólnoadministracyjne”). Koszty okresu prezentowane były oddzielnie w ramach dwóch wspomnianych pozycji, choć zdarzały się wyjątki. Jedna z grup kapitałowych zaprezentowała koszty zarządu i sprzedaży w ramach jednej pozycji, wyodrębniając z niej i prezentując oddzielnie „koszty usługi dystrybucyjnej”. Inna nie zaprezentowała w ogóle kosztów sprzedaży, podając tylko wartość kosztów ogólnego zarządu.

W przypadku grup kapitałowych sporządzających rachunek wyników w wariancie porównawczym sytuacja wyglądała odmiennie. W sposób typowy dla układu rodzajowego koszty działalności podstawowej zaprezentowała mniej niż połowa badanych (45,5\%). Pozostałe grupy kapitałowe stosowały odmienny sposób prezentacji dostosowany do specyfiki prowadzonej działalności, a dokładne określenie, co się pod daną pozycją kryje, wymagało sięgnięcia do not objaśniających. I tak np. w jednej z grup wyodrębniono następujące pozycje: „koszty zakupów zewnętrznych”, „koszty świadczeń pracowniczych”, „pozostałe koszty operacyjne”, „koszty rozwiązania stosunku pracy i amortyzacja". W innej natomiast obok amortyzacji (prezentowanej oddzielnie dla środków trwałych i wartości niematerialnych) oraz kosztów zużycia materiałów i energii wyodrębniono: „koszty związane z ofertą publiczną”, „z zakupami spółek zależnych oraz restrukturyzacją”, „,koszty programu opcji pracowniczych”, a także pozostałe „usługi obce i pozostałe koszty wynagrodzeń i świadczeń". Jeszcze inna badana grupa w rachunku zysków i strat zaprezentowała zbiorczo pozycję „koszty operacyjne”, które szczegółowo zostały przedstawione zgodnie z układem rodzajowym dopiero w notach objaśniających.

Omawiając sposób prezentacji kosztów działalności podstawowej, warto również wskazać, że różna była prezentacja pozycji kosztowo przychodowych w ramach pozostałej działalności operacyjnej i działalności finansowej. W przypadku tej pierwszej na odrębną prezentację pozostałych kosztów operacyjnych i pozostałych przychodów operacyjnych zdecydowało się 90\% badanych, przy czym w niektórych przypadkach wyodrębniane były również bardziej szczegółowe pozycje. Po- 
zostałe $10 \%$ badanych zaprezentowało pozostałe przychody i koszty operacyjne łącznie w postaci salda netto. Również w ramach działalności finansowej znaczna większość badanych zdecydowała się na odrębną prezentację przychodów i kosztów finansowych (92\% badanych), choć tylko $60 \%$ z nich przedstawiło dodatkowo pozycję „udział w zyskach (stratach) jednostek stowarzyszonych”, której prezentacja jest wymagana przez MSR 1.

Przeprowadzona analiza rachunków wyników badanych grup kapitałowych wykazała również, że różnią się one między sobą ilością wyodrębnianych cząstkowych wyników finansowych. Spośród wszystkich grup kapitałowych sporządzających rachunek zysków i strat metodą kalkulacyjną aż trzy czwarte, tj. 71,7\%, zaprezentowało $\mathrm{w}$ rachunku zysków i strat cztery poziomy wyniku finansowego, tj. zysk brutto ze sprzedaży, zysk z działalności operacyjnej, wynik brutto (nazywany bardzo często zyskiem (wynikiem) przed opodatkowaniem) oraz zysk netto. Wszystkie te podmioty zrezygnowały z prezentacji wyniku ze sprzedaży, łącząc koszty zarządu i sprzedaży z pozostałymi kosztami i przychodami operacyjnymi i prezentując po wyniku brutto ze sprzedaży od razu wynik z działalności operacyjnej². Taki sposób prezentacji informacji jest zbieżny, a w wielu przypadkach wręcz identyczny z publikowanymi przez firmy audytorskie i doradcze wzorcowymi sprawozdaniami finansowymi. W rachunku zysków i strat $15,4 \%$ badanych grup wyodrębnionych zostało pięć poziomów wyniku finansowego (w tym dodatkowo zysk ze sprzedaży), zaś w przypadku 7,7\% tylko trzy. Najczęściej rezygnowano z prezentacji zarówno wyniku brutto ze sprzedaży, jak i wyniku ze sprzedaży, a pierwszym poziomem był wynik z działalności operacyjnej. Zdarzały się również bardziej niestandardowe podejścia. Jedna z grup zaprezentowała zysk brutto ze sprzedaży, zysk ze sprzedaży i od razu zysk przed opodatkowaniem - nie wydzielając wyniku operacyjnego.

Biorąc pod uwagę wielkość grupy kapitałowej, należy stwierdzić, że pod analizowanym względem rachunki zysków i strat podmiotów z indeksu WIG20 były do siebie bardziej zbliżone. Aż $90,9 \%$ z nich prezentowało identyczne cząstkowe poziomy wyniku finansowego bez uwzględniania wyniku ze sprzedaży. Większe różnice dotyczą zatem grup mniejszych, wchodzących w skład indeksu mWIG40.

Analizując natomiast grupy kapitałowe sporządzające rachunek zysków i strat zgodnie z wariantem porównawczym, to znaczna większość - prawie 2/3 (tj. 63,6\%) wszystkich - nie zaprezentowała, podobnie jak we wcześniejszej grupie, wyniku ze sprzedaży. Pierwszym wynikiem finansowym, jaki został wyliczony, był wynik z działalności operacyjnej. Warto dodać, że jedna z grup kapitałowych nie wyodrębniła również wyniku przed opodatkowaniem, prezentując tylko wynik operacyjny oraz wynik netto. Inna z kolei, zamiast wyniku ze sprzedaży, zaprezentowała wynik

\footnotetext{
${ }^{2}$ Zdarzały się również sytuacje, w których stosowane było błędne nazewnictwo poziomów wyniku finansowego. W jednej z badanych grup kapitałowych zyskiem ze sprzedaży określono zysk brutto ze sprzedaży. Nie obejmował on kosztów okresu (zarządu i sprzedaży), a te zostały zaliczone do pozostałej działalności operacyjnej.
} 
EBITDA, jeszcze inna wyodrębniła, obok wyniku EBITDA, dodatkowy poziom wyniku - EBITDAR ${ }^{3}$. Tak różne podejścia w konstrukcji rachunku wyników badanych spółek, choć zgodne z zapisami MSR1, mogą jednak powodować znaczne trudności w porównaniu wyników osiąganych przez różne podmioty, a także w analizie i interpretacji wskaźników finansowych.

Dalsza część przeprowadzonego badania została poświęcona prezentacji informacji dotyczących innych całkowitych dochodów. Rozpoczęto je od określenia rodzaju wyniku (dodatni czy ujemny) generowanego przez badane podmioty w tej części sprawozdania. Uzyskane wyniki przedstawiono w tabeli 2.

Tabela 2. Badane grupy ze względu rodzaj wyniku z innych całkowitych dochodów

\begin{tabular}{|l|c|c|c|c|c|c|}
\hline \multirow{2}{*}{ Rodzaj wyniku } & \multicolumn{2}{|c|}{$\mathbf{2 0 1 5}$} & \multicolumn{2}{c|}{$\mathbf{2 0 1 6}$} & \multicolumn{2}{c|}{$\mathbf{2 0 1 7}$} \\
\cline { 2 - 7 } & $\mathbf{N}$ & $\mathbf{\%}$ & $\mathbf{N}$ & $\mathbf{\%}$ & $\mathbf{N}$ & $\mathbf{\%}$ \\
\hline dodatni (zysk) & 27 & $45,0 \%$ & 35 & $58,3 \%$ & 25 & $41,7 \%$ \\
\hline ujemny (strata) & 28 & $46,7 \%$ & 21 & $35,0 \%$ & 32 & $53,3 \%$ \\
\hline brak OCI & 5 & $8,3 \%$ & 4 & $6,7 \%$ & 3 & $5,0 \%$ \\
\hline Razem & $\mathbf{6 0}$ & $\mathbf{1 0 0 , 0} \%$ & $\mathbf{6 0}$ & $\mathbf{1 0 0 , 0} \%$ & $\mathbf{6 0}$ & $\mathbf{1 0 0 , 0} \%$ \\
\hline
\end{tabular}

Źródło: opracowanie własne.

Otrzymane wyniki pokazują dużą zmienność wyniku z innych całkowitych dochodów w badanym okresie. W roku 2015 udział badanych podmiotów generujących zysk i stratę z OCI był prawie identyczny. W roku 2016 więcej podmiotów generowało zysk (58,3\%) niż stratę (35\%), a w roku 2017 tendencja była odwrotna stratę z OCI wykazało $53,3 \%$ badanych, a zysk $41,7 \%$. Ponadto w badanym okresie zmniejszył się odsetek podmiotów, które w ogóle nie wykazywały OCI z 8,3\% do $5 \%$. Takiego zróżnicowania nie zaobserwowano natomiast w przypadku bieżącego wyniku netto, gdyż znaczna większość grup kapitałowych wykazywała w badanym okresie zysk. Było to odpowiednio $86,7 \%$ w roku $2015,88,3 \%$ w roku 2016 i aż $90 \%$ w roku 2017.

Analizując bardziej szczegółowo uzyskane wyniki ze względu na wielkość badanej grupy kapitałowej, okazuje się, że w przypadku grup dużych z indeksu WIG20 zysk z innych całkowitych dochodów wykazało w 2017 roku 55\% badanych podmiotów, w roku 2016 było to $65 \%$ i odsetek ten był identyczny w roku 2015 . W przypadku grup mniejszych z indeksu mWIG40 odsetek ten wyniósł odpowiednio 55\% w roku 2016 i zaledwie 35\% w roku 2017 i 2015.

Ze względu na fakt, że wykazywany przez badane podmioty wynik z innych całkowitych dochodów miał w badanym okresie różną wartość, policzono wskaźnik udziału OCI w wyniku netto spółki (EAT), ale bez uwzględniania jego charakteru

\footnotetext{
${ }^{3}$ Zgodnie z informacją zawartą w rachunku wyników podmiotu, jest to wynik operacyjny bez zdarzeń jednorazowych, powiększony o amortyzację oraz koszt wynajmu nieruchomości.
} 
- zysk/strata. Taka analiza miała pokazać, w jakim stopniu inne całkowite dochody mogą wpływać na wynik finansowy netto i tym samym czy mają one istotne znaczenie z punktu widzenia kreowania wyniku finansowego. Średnia wartość wskaźnika udziału OCI w EAT dla całej badanej grupy wyniosła w roku 2015 19,2\%, przy odchyleniu standardowym $(s)$ na poziome 46,4\%. W roku 2016 wzrosła do poziomu $22,7 \%(s=42,8 \%)$, a w roku 2017 uległa zmniejszeniu do poziomu $14,3 \%$ $(s=21 \%)$. Uzyskane wartości potwierdzają, że inne całkowite dochody stanowiły w badanym okresie niedużą część generowanego wyniku netto, ale wysokie odchylenie standardowe wskazuje na duże różnice w jego wartości między poszczególnymi podmiotami. Potwierdza to wnioski płynące $\mathrm{z}$ badań prowadzonych przez A. Szychtę [2012, s. 73].

Ze względu na duże zróżnicowanie wartości wskaźnika udziału badane podmioty podzielono na trzy grupy. Do pierwszej z nich zaliczono te, dla których udział OCI w EAT nie przekroczył 10\%, do drugiej te, dla których udział ten kształtował się w przedziale od 10 do $50 \%$, a do trzeciej te, dla których udział przekroczył 50\%. Otrzymane wyniki zostały zebrane w tabeli 3 .

Tabela 3. Badane grupy ze względu na wartość wskaźnika udziału OCI w EAT

\begin{tabular}{|l|c|c|c|c|c|c|}
\hline \multirow{2}{*}{ Wartość wskaźnika } & \multicolumn{2}{|c|}{$\mathbf{2 0 1 5}$} & \multicolumn{2}{c|}{$\mathbf{2 0 1 6}$} & \multicolumn{2}{c|}{$\mathbf{2 0 1 7}$} \\
\cline { 2 - 7 } & $\mathbf{N}$ & $\mathbf{\%}$ & $\mathbf{N}$ & $\mathbf{\%}$ & $\mathbf{N}$ & $\mathbf{\%}$ \\
\hline do $10 \%$ & 35 & $58,3 \%$ & 29 & $48,3 \%$ & 33 & $55,0 \%$ \\
\hline $10,01 \%$ do $50 \%$ & 15 & $25,0 \%$ & 19 & $31,7 \%$ & 21 & $35,0 \%$ \\
\hline powyżej $50 \%$ & 5 & $8,3 \%$ & 8 & $13,3 \%$ & 3 & $5,0 \%$ \\
\hline brak & 5 & $8,3 \%$ & 4 & $6,7 \%$ & 3 & $5,0 \%$ \\
\hline Razem & $\mathbf{6 0}$ & $\mathbf{1 0 0 , 0} \%$ & $\mathbf{6 0}$ & $\mathbf{1 0 0 , 0 \%}$ & $\mathbf{6 0}$ & $\mathbf{1 0 0 , 0} \%$ \\
\hline
\end{tabular}

Źródło: opracowanie własne.

Jak wynika $\mathrm{z}$ danych przedstawionych w tabeli 3, inne całkowite dochody nie stanowią znaczącej wartości wyniku finansowego netto. W roku 2015 dla 58,3\% badanych ich udział nie przekroczył $10 \%$, a w przypadku jednej czwartej kształtował się w przedziale od 10 do 50\%. W roku 2016 udział OCI w EAT zwiększył się nieznacznie. Udział podmiotów, w których analizowany wskaźnik nie przekroczył $10 \%$ zmalał do 48,3\%, zwiększył się natomiast udział tych, dla których wskaźnik nie przekroczył 50\% (wzrósł do poziomu 31,7\%). W roku 2017 ponownie zwiększył się udział podmiotów, dla których wartość wskaźnika nie przekroczyła $10 \%$ - do poziomu 55\%, jak i tych, dla których wskaźnik ten wahał się w przedziale od 10 do $50 \%$ - wzrost do poziomu $35 \%$. I choć uzyskane wyniki pokazują, że tylko dla niewielkiej liczby badanych OCI stanowiły ponad połowę EAT, to zdarzały się pojedyncze przypadki, w których analizowany wskaźnik był bardzo wysoki i wynosił ponad $250 \%$. 
Dalsza analiza sprawozdania z całkowitych dochodów skupiła się na określeniu, jakie koszty lub przychody zaliczane do innych całkowitych dochodów występują w badanych grupach kapitałowych i jak są przez nie prezentowane. Analiza wykazała, że w $80 \%$ badanych sprawozdań OCI były prezentowane zgodnie z wymaganiami MSR1, tj. w podziale na dwie odrębne grupy, czyli pozostałe całkowite dochody podlegające reklasyfikacji do rachunku zysków i strat oraz te, które takiemu przeklasyfikowaniu nie będą podlegały. W przypadku pozostałych $20 \%$ takiego podziału nie dokonano, a OCI prezentowane były razem. Oznacza to, że aż jedna piąta badanych grup kapitałowych nie wywiązała się z obowiązku wynikającego z MSR 1. Warto dodać, że podział na dwa typy OCI był częściej stosowany w przypadku dużych grup kapitałowych z indeksu WIG20 - stosowało go aż 95\% z nich. W przypadku grup mniejszych podział na dochody podlegające i niepodlegające przeniesieniu do rachunku zysków i strat zastosowano u 72,5\% podmiotów.

Analizując wykazywane w sprawozdaniach inne całkowite dochody, należy powiedzieć, że te, które mogą być przeklasyfikowane do rachunku zysków i strat, występowały częściej - w przypadku $80 \%$ badanych sprawozdań. Te niepodlegające przeniesieniu pojawiły się natomiast w $66,7 \%$. W przypadku innych całkowitych dochodów podlegających reklasyfikacji wyodrębniono osiem różnych pozycji. Najczęściej wykazywane były różnice kursowe dotyczące przeliczenia jednostek działających za granicą $(60 \%)$, odroczony podatek dochodowy ${ }^{4}(50 \%)$, instrumenty zabezpieczające przepływy pieniężne $(31,3 \%)$ oraz różnice wyceny aktywów finansowych dostępnych do sprzedaży (30\%). W przypadku innych całkowitych dochodów niepodlegających przeniesieniu do rachunku zysków i strat najczęściej wykazywano zyski i straty aktuarialne związane ze świadczeniami pracowniczymi $(58,3 \%)$ oraz odroczony podatek dochodowy $(53,3 \%)$. Inne pozycje występowały sporadycznie, a ich udział nie przekroczył $5 \%$.

Na uwagę zasługuje również fakt, że wymienione wyżej pozycje OCI były w badanych sprawozdaniach określane różnymi nazwami, a liczba określeń dotyczących tej samej pozycji była zaskakująco duża. W przypadku pozycji „Różnice kursowe z przeliczenia jednostek działających za granicą" na 36 sprawozdań, w których wystąpiła, naliczono aż 13 różnych nazw. W przypadku pozycji zyski/straty aktuarialne było ich aż 20 i to często bardzo mocno różniących się od siebie, np. „Kapitał i wycena rezerw na świadczenia pracownicze”, „Udział w skutkach przeszacowania zobowiązań z tytułu określonych świadczeń pracowniczych” czy nawet „Przeszacowanie programu określonych świadczeń".

Jeżeli chodzi o sposób prezentacji innych całkowitych dochodów, to $67,9 \%$ badanych, w których OCI występowało, wykazywało je w wartościach brutto, prezentując oddzielnie wartości korekty podatku dochodowego. Prezentację w kwotach netto wybrało $14,3 \%$, a w przypadku $17,8 \%$ ocena wybranego wariantu nie była możliwa.

\footnotetext{
${ }^{4} \mathrm{~W}$ niektórych przypadkach nie stanowił on odrębnej grupy, lecz był uwzględniany bezpośrednio we wcześniejszych pozycjach - prezentacja OCI w kwotach netto.
} 
Nie występowała odrębna pozycja dotycząca podatku dochodowego, a w nazwie prezentowanych OCI nie zaznaczono, w jaki sposób są podawane ich wartości.

\section{Zakończenie}

Przeprowadzona analiza sprawozdań z całkowitych dochodów największych grup kapitałowych notowanych na GPW w Warszawie za lata 2015-2017, dotycząca sposobu prezentacji informacji o kosztach i innych całkowitych dochodach, pozwala na wyciągnięcie wielu istotnych wniosków. Jeżeli chodzi o strukturę samego dokumentu, to należy przede wszystkim wskazać, że badane grupy znacznie częściej prezentują informacje o wyniku finansowym w ramach dwóch odrębnych zestawień, tj. rachunku zysków i strat oraz sprawozdania z innych całkowitych dochodów, a otrzymane wyniki są zgodne z wynikami wcześniejszych badań prowadzonych w tym zakresie. Ponadto $\mathrm{w}$ rachunku zysków i strat dominuje prezentacja informacji kosztowych dotyczących działalności podstawowej według miejsc powstawania i nośników kosztów (wariant kalkulacyjny). Wariant porównawczy częściej wybierają firmy z branży telekomunikacyjnej oraz medialnej. Wart podkreślenia jest również fakt, że badane grupy wykorzystują swobodę, jaką daje MSR 1 zarówno w zakresie struktury samego sprawozdania z całkowitych dochodów, jak i stosowanego w nim nazewnictwa. W strukturze zauważalny jest różny sposób grupowania kosztów oraz różna liczba wyodrębnianych cząstkowych wyników finansowych, przy czym większe różnice występują wśród podmiotów sporządzających rachunek wyników zgodnie z wariantem porównawczym. Jeśli zaś chodzi o różnice w nazewnictwie, to dotyczą one zarówno nazwy samego sprawozdania, jak i poszczególnych jego elementów składowych, przy czym znacznie większe różnice występują w pozycjach innych całkowitych dochodów niż tych z podstawowego rachunku zysków i strat. Przedstawione wnioski dotyczące różnego sposobu prezentacji informacji w sprawozdaniu z całkowitych dochodów pozwalają na pozytywną weryfikację postawionej we wstępie opracowania hipotezy badawczej.

Należy jednak wskazać, że duża swoboda, jaką daje MSR 1, oraz brak jednolitego wzorca sprawozdania $\mathrm{z}$ całkowitych dochodów skłania do poszukiwania gotowych rozwiązań. Widoczne jest sporządzanie tego dokumentu według wzorców publikowanych przez uznane firmy audytorskie i doradcze.

Jeśli chodzi natomiast o wnioski dotyczące prezentacji innych całkowitych dochodów, to należy rozpocząć od stwierdzenia, że udział OCI w stosunku do wyniku netto pozostaje niezbyt wysoki. W roku 2017 stanowił on średnio 14,3\% i zmniejszył się w stosunku do roku 2016. Ponadto dla ponad połowy badanych wartość tego wskaźnika nie przekroczyła $10 \%$. Mimo niezbyt wysokiego udziału innych całkowitych dochodów, jego zróżnicowanie między badanymi grupami jest duże, a świadczy o tym wysoka wartość odchylenia standardowego w całym badanym okresie. Ponadto wartość wyniku z OCI (dodatnia, ujemna) podlega dużym zmia- 
nom w poszczególnych latach w przeciwieństwie do bieżącego wyniku netto - zysk netto generowało w całym badanym okresie ponad 85\% grup kapitałowych.

Należy również wskazać, że badane podmioty częściej prezentują inne całkowite dochody w wartościach brutto, choć nie zawsze jest możliwe jednoznaczne określenie przyjętego sposobu prezentacji. Ponadto nie wszyscy badani wywiązują się z obowiązku prezentacji innych całkowitych dochodów z podziałem na dwie grupy, tj. te, które podlegają, i te, które nie podlegają przeklasyfikowaniu do rachunku zysków i strat, znacznie lepiej ten obowiązek wypełniają grupy duże z indeksu WIG20.

Podsumowując, przeprowadzona analiza pokazała znaczące różnice w sposobie prezentacji informacji o kosztach $\mathrm{i}$ innych całkowitych dochodach w sprawozdaniach finansowych, co może mieć istotny wpływ na wykorzystywanie tych informacji przez zewnętrznych użytkowników. Uzyskane wyniki potwierdzają również wnioski płynące z wcześniej prowadzonych badań w tym zakresie, co powoduje, że pozostają one cały czas aktualne.

\section{Literatura}

Bek-Gaik B., 2013a, Sprawozdanie z całkowitych dochodów jako nowy element sprawozdania finansowego - wybrane aspekty teoretyczne i praktyczne, Zeszyty Naukowe US, Finanse, Rynki Finansowe, Ubezpieczenia, nr 59, s. 21-37.

Bek-Gaik B., 2013b, Sprawozdawczy wymiar rachunku wyników w warunkach globalnego rynku, Wydawnictwo Uniwersytetu Łódzkiego, Łódź.

Buk H., 2013, Zróżnicowana informacja o dochodach spółki w zależności od stosowanych standardów sprawozdawczości finansowej, Acta Universitatis Lodziensis. Folia Oeconomica, nr 278, s. 7-17.

Deloitte, 2015, Wzorcowe Skonsolidowane Sprawozdanie Finansowe 2015 wedtug MSSF w ksztatcie zatwierdzonym przez Unię Europejską, www.iasplus.com/en/publications/poland/models/2015/ at_download/file/Wzor_Skonsolid_Sprawozdania_MSSF_wg_UE_31\%2012\%202015_PDF_ POL.pdf (31.05.2018).

Emerling I., 2014, Rachunek zysków i strat $w$ świetle rozwiązań międzynarodowych, Studia Ekonomiczne. Zeszyty Naukowe Uniwersytetu Ekonomicznego w Katowicach, nr 190, s. 42-52.

Gad J., 2016, Information transparency of the statement of comprehensive income: The Reporting practice of WIG30 and DAX Companies, Journal of Entrepreneurship and Innovation, vol. 12, issue 3, s. $113-134$

Gierusz J., 2014, Reklasyfikacja kosztów i przychodów ze sprawozdania z całkowitych dochodów do rachunku zysków i strat - przyczyny, zakres, konsekwencje, Zarządzanie i Finanse, vol. 12, s. 189-204.

Grabiński K., 2012, Sprawozdanie z zysku całkowitego a bieżacy zysk operacyjny - użyteczność decyzyjna w świetle badań naukowych, Zeszyty Teoretyczne Rachunkowości, nr 66, s. 48-49.

Hołda A., 2013, MSR/MSSF w polskiej praktyce gospodarczej, Wydawnictwo C.H. Beck, Warszawa.

MSR 1 - Prezentacja sprawozdań finansowych.

PWC, 2015, Przykładowe skonsolidowane sprawozdanie finansowe wedtug MSSF, PWC www.pwc. $\mathrm{pl} / \mathrm{pl} / \mathrm{publikacje} / 2015 / \mathrm{przykladowe}-$ skonsolidowane-sprawozdanie-finansowe-mssf-2015.html (31.05.2018).

Sajnóg A., 2014, Rola zysku całkowitego w ocenie dokonań spółek giełdowych, Zeszyty Naukowe US, Finanse, Rynki Finansowe, Ubezpieczenia, nr 66, s. 475-487.

Skonsolidowane sprawozdania finansowe za rok 2017, 2016 i 2015 grup kapitałowych wchodzących w dniu 15 maja w skład indeksów WIG20 i mWIG40. 
Strojek-Filus M., 2015, Pomiar i prezentacja dokonań finansowych jednostki gospodarczej w sprawozdaniu z całkowitych dochodów, Studia Ekonomiczne. Zeszyty Naukowe Uniwersytetu Ekonomicznego w Katowicach, nr 240, s. 125-141.

Szychta A., 2011, Wynik całościowy w sprawozdaniach finansowych spótek publicznych, [w:] Sobańska I., Turzyński M. (red.), Rachunkowość, audyt i kontrola w zarzadzaniu, Wydawnictwo Uniwersytetu Łódzkiego, Łódź, s. 81-108.

Szychta A., 2012, Dochody całkowite w sprawozdaniach finansowych największych spółek notowanych na GPW w Warszawie, Acta Universitatis Lodziensis, Folia Oeconomica 2012, nr 263, s. 65-88.

Walińska E., Jurewicz A., 2011, Ewolucja sprawozdania finansowego w wymiarze międzynarodowym, [w:] Walińska E. (red.), Sprawozdanie finansowe wedtug MSSF. Zasady prezentacji i ujawniania informacji, Oficyna Wolters Kluwer business, Warszawa, s. 23-31.

Winnicka E., 2013, Zmiany w MSR 1 a praktyka wybranych spótek notowanych na GPW w Warszawie, Copernican Journal of Finance \& Accounting, vol. 2, s.169-189. 